\title{
Causes of entropion... think about trachoma
}

\section{Causas de entropión... pensar en tracoma}

René H. Parada-Vásquez¹, Victor E. Lomas-Guaman² and Carlos R. León-Roldán²

${ }^{1}$ Anterior segment, Vision Institute, Hospital La Carlota, Montemorelos, N.L., Mexico; ${ }^{2}$ School of Ophthalmology, Centro Oftalmológico León, Guatemala, Guatemala

A 38-year-old male patient without relevant medical history. Physical examination shows: Corrected visual acuity in the right eye $20 / 20$, left eye $20 / 60$. Right eye without abnormal findings. Left eye shows irregular white lines of conjunctival scarring that converge in a horizontal zone (Arlt's line) in the upper tarsal conjunctiva. The cicatricial process causes retraction of the upper eyelid, generating entropion and being the cause of trichiasis (Fig. 1). The lower eyelid shows follicular necrosis with scar tissue (Fig. 2). Giemsa staining for Chlamydia inclusion bodies was positive.

\section{Ethical disclosures}

Protection of human and animal subjects. The authors declare that no experiments were performed on humans or animals for this study.

Confidentiality of data. The authors declare that no patient data appear in this article.

Right to privacy and informed consent. The authors declare that no patient data appear in this article.

\section{Funding}

The authors received no specific funding for this work.

\section{Conflicts of interest}

The authors declare no conflicts of interest.

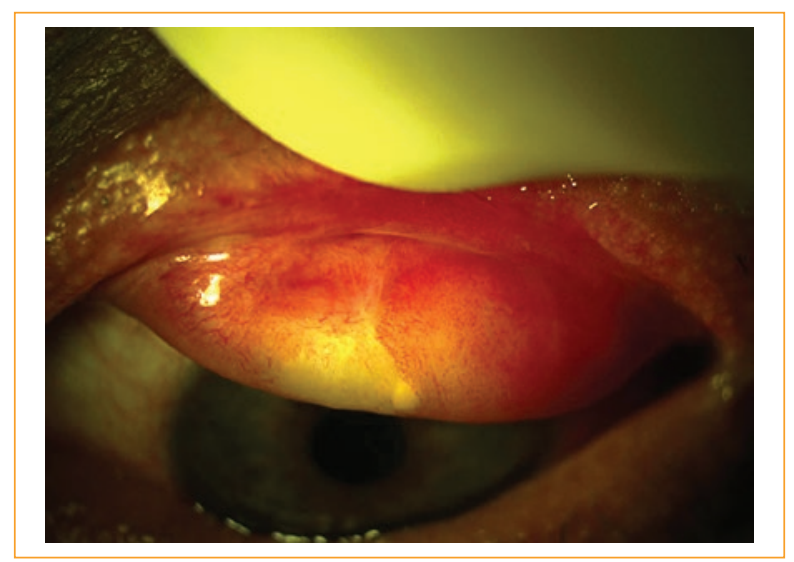

Figure 1. Arlt's line in the upper tarsal conjunctiva of the left eye.

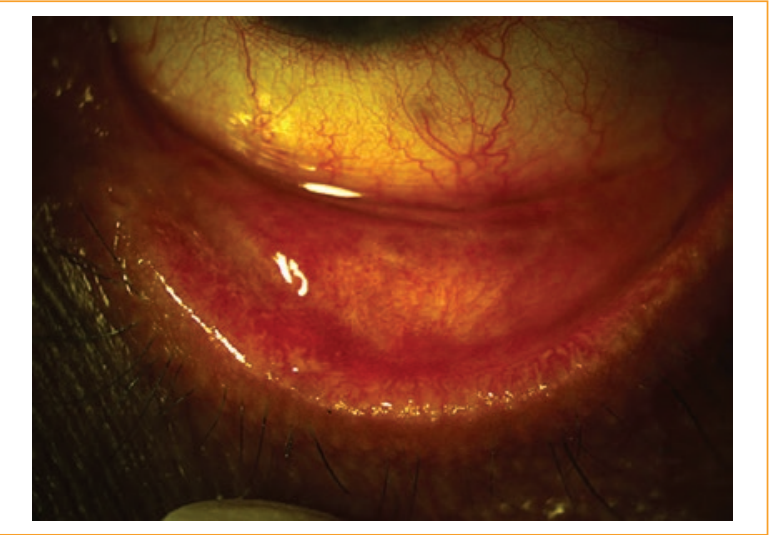

Figure 2. Lower eyelid shows follicular necrosis with scar tissue.

\section{Correspondence:}

*René Hernán Parada-Vásquez E-mail: rene_hernan@ @otmail.com
Available online: 01-11-2018 Rev Mex Oftalmol (Eng). 2018;92(6):274 www.rmo.com.mx 2604-1731/@ 2018 Sociedad Mexicana de Oftalmología. Published by Permanyer México SA de CV. This is an Open Access article under the CC BY-NC-ND license (http://creativecommons.org/licenses/by-nc-nd/4.0/). 